\title{
HISTORICAL AND GEOPOLITICAL ANALYSIS OF NŪR AL-DĪN MAHMŪD ZANKĪ'S PLAN FOR LIBERATING BAYT AL-MAQDIS
}

\author{
Burhan CHE DAUD, ${ }^{*}$ Abd al-Fattah EL-AWAISI,"* Mohd Roslan MOHD NOR
}

\begin{abstract}
Nūr al-Din Mahmūd Zanki was one of the $6^{\text {th }}$ century AH Muslims leaders who particularly had thought very carefully of how to liberate Bayt al-Maqdis. The main objective of this article is namely to examine Nür al-Dïn's preparation plan to liberate Bayt al-Maqdis, in particular if he had prepared the ground to achieve such a goal which was successfully accomplished during the time of his successor, Saläh al-Dīn al-Ayyūbi. In addition to the religious impact, this article examines the remaining material evidence and the practical steps that had been taken by Nür al-Din throughout twentyeight years of his career to construct a strong and a solid argument concerning his clear and distinctive plan towards liberating Bayt al-Maqdis. The main focus is on examining his preparation steps towards the unification of Syria and afterwards the unification of Syria with Egypt.
\end{abstract}

KEYWORDS: Bayt al-Maqdis, Islamicjerusalem, Nūr al-Dīn Zankī, Crusades, Jerusalem, Saläh al-Dìn.

\section{INTRODUCTION}

Nūr al-Dīn Mahmūd Zankī (511-569 AH/1118-1174 CE), known as Al-Malik al-ç̄dil, was a member of the Zankī dynasty, who ruled Bilad al-Sham (Historical Syria) and Syria in particular from 541 to $569 \mathrm{AH} / 1146$ to $1174 \mathrm{CE}$ after the death of his father, 'Imād al-Dīn Zankī. He succeeded his father in Aleppo in 541 AH/1146 CE while Mosul was put under the control of his brother, Sayf al-Dīn Ghāzī. What was so special about Nūr al-Din that he was one of the $6^{\text {th }}$ century AH Muslims leaders who particularly had thought very carefully of how to liberate Bayt alMaqdis/ Islamicjerusalem. ${ }^{1}$ Since the occupation of Bayt al-Maqdis by the Crusaders in $492 \mathrm{AH} / 1099 \mathrm{CE}$, none of the Muslims leaders in Bilad al-Sham (Historical Syria) had a closer connection with Bayt al-Maqdis stronger than that of Nūr al-Dīn. The atmosphere in which he lived and the various situations he faced made him an experienced leader to plan for the liberation of Bayt alMaqdis.

\footnotetext{
* Centre for Languages studies and Human Development, Universiti Malaysia Kelantan, MALAYSIA. burhan@umk.edu.my

** Professor of International Relations, Social Sciences University of Ankara (ASBU), TURKEY, a.elawaisi@gmail.com

*** Academy of Islamic Studies, Universiti Malaya (UM), MALAYSIA. m_roslan@um.edu.my
} 
However, focusing mainly on the religious impact might not be sufficient to build up a solid argument that Nūr al-Dīn has a clear and distinctive plan towards liberating Bayt al-Maqdis. Therefore, examining the remaining material evidence and the practical steps that had been taken by Nūr al-Dīn throughout twenty-eight years of his career would strengthen the previous evidences and construct a strong argument concerning his plan for Bayt al-Maqdis. At this stage, we focus mainly on examining his preparation steps which had been put into operation by Nūr al-Dīn towards the unification of Bilad al-Sham and afterwards the unification of Bilad al-Sham with Egypt. The main objective of this article is namely to examine Nūr al-Dīn's preparation plan to liberate Bayt alMaqdis, in particular if he had prepared the ground to achieve such a goal which was successfully accomplished during the time of his successor, Salāh al-Dīn alAyyūbì, in $583 \mathrm{AH} / 1187 \mathrm{CE}$.

\section{METHODS}

This article depends mainly on a number of primary sources, such as Ibn al-Athir, (born 1160, died 1233 CE), and Abu Shamah, (born 1203, died 1267 CE); and secondary historical references. Although none of the primary sources can be considered as written at the time of Nur al-Din ruling period (first hand), they are very close to his period. For example, Ibn al-Athir was 14 years old when Nur alDin died in $1174 \mathrm{CE}$.

Dealing with translating original texts from Arabic to English, the authors employed El-Awaisi's approach. "When translating terminologies from Arabic into English, an attempt has been made by the author to strike a balance between the strength of expression in the original and its exact meaning. However, to avoid the mistranslating of any particular Arabic terminologies, the author employed an approach of not translating these into English but leaving them in their original Arabic language which helps to avoid any leading to different or strange understandings and interpretations" (El-Awaisi, 2007: 4).

Moreover, the authors have also adopted El-Awaisi's historical methodology where they endeavoured in their analysis to "concentrate on and look with complete openness at most if not all of the aspects surrounding the issue under discussion and focus on the key and fundamental ones related to the topic". (El-Awaisi, 2007: 3-4). They also adopted El-Awaisi's interdisciplinary and multidisciplinary approaches; and his new geopolitical theory, the Barakah Circle Theory of Bayt al-Maqdis.

\section{RESULTS/FINDINGS AND DISCUSSION}

\section{Nūr al-Dīn Zanki's Plan for Bayt al-Maqdis}

Hillenbrand (1999: 150) argues that it is difficult to pinpoint precisely when Muslim leaders began to focus their attention on the liberation of Bayt al-Maqdis as an integral or central part of their aims. Apart from the Fatimid initiative, immediately after the Crusaders' occupation of Bayt al-Maqdis in $492 \mathrm{AH} / 1099 \mathrm{CE}$, 
the loss of Bayt al-Maqdis did not prompt any further effective attempts on the part of the Muslims to liberate it from the Crusaders. Nevertheless, the Muslim victory at Edessa in $539 \mathrm{AH} / 1144 \mathrm{CE}$ under the leadership of 'Imād al-Dīn Zanki could be the key turning point for them in launching further Jihäd against the Crusaders. Hillenbrand (1999: 150) also argues that Bayt al-Maqdis began to appear in the Muslim agenda as a focus for Jihäd against the Crusaders in the last years of 'Imād al-Dīn's life. Newby (1983: 22) seems to be in agreement with this argument. He argues that the capture of Damascus seems to have been the height of 'Imād al-Dīn's ambition. He might have thought of attacking the Latin Kingdom of Jerusalem after becoming the leader of the three key cities in Syria; Damascus, Aleppo and Mosul.

However, the momentum for the liberation of Bayt al-Maqdis was considerably augmented during the ruling period of Nūr al-Dìn. At some point in his reign, Bayt al-Maqdis became a major theme of the programme of Jihād. Hillenbrand (1999: 150) argues that during Nūr al-Dīn's career, Bayt al-Maqdis became his ultimate ambition and focus, although it is not clear precisely when this took place during the twenty-eight years of his career.

\section{Evidences}

To understand and interpret Nūr al-Dīn Zanki's Plan for Bayt al-Maqdis, this section will examine the following evidences: religious impact, Nūr al-Dīn's preparations and practical steps towards liberating Bayt al-Maqdis, and the construction of the Minbar (Pulpit) as a remaining evidence of his plan.

\section{Religious Impact}

Examining historical sources, shows that Bayt al-Maqdis had a special status for Nūr al-Dīn which connected with him religiously and spiritually. The call for Jihād by the well-known jurists and philologist from Damascus, al-Sulami, ${ }^{2}$ in $499 \mathrm{AH} /$ $1105 \mathrm{CE}$, some forty years before his reign seems to have influenced his thought on liberating Bayt al-Maqdis. Moreover, the emergence of such concern during Nür al-Din's reign may well be closely connected to his intimate relationship with the religious groups in Syria. Hillenbrand (1999: 119) argues that an important aspect of the development of the religious image of Nūr al-Din was the patronage, which Nūr al-Dīn extended to the religious classes of Syria and the increasingly close relationship he enjoyed with them. As a result, those religious classes were directly involved in the military campaigns of Nūr al-Dīn in which Elisseeff (1967, 3: 735) argues that the army of Nūr al-Dīn contained religious men, prayer leaders, al-Qur'ān readers, preachers, judges as well as lawyers and mystics who were actually prepared to fight in the ranks.

In addition, Nūr al-Dīn's intimate affiliation with the religious classes might have influenced his policies and approaches during the process of number of conquests in Bilad al-Sham (Historical Syria) including Bayt al-Maqdis. For instance, Nūr al-Dīn had a strong relationship with Ibn 'Asākir, the famous Muhaddith and historian who was the head of Där al-Hadith al-Nūriyyah (Al- 
Nūriyyah Centre for Hadīth Scholarship) in Damascus. Abū Shāmah narrated an account from al-Hasan Ibn Hibatullah who had attended a circle of hadith with his uncle Ibn 'Asākir in Damascus. Al-Hasan described the concern of Nūr al-Dīn regarding the practice of the Sunnah of Prophet Muhammad. In that particular occasion, Nūr al-Dīn and the audience came across a hadith which described that Prophet Muhammad used to hold his sword when he went out for any campaign. Comparing the practice of his army with that of the Prophet, Nūr alDin concluded that his army was not doing the same. Accordingly, on the following day, he changed the way of holding sword to be similar to what Prophet Muhammad had done (Abū Shāmah, 1956, 1: 27-28). Moreover, Nūr alDin also had benefited from his regular correspondence with another wellknown preacher, jurist and historian Ibn al-Jawzī who was in Baghdād at that time (Ibn al-Jawzī, 1995, 8: 209-210).

Moreover, the emergence of several writings and poems about Jihād and Fadā'il Merits of Bayt al-Maqdis and al-Aqsā Mosque in particular may have also played its part in developing his concerns towards Bayt al-Maqdis. Mujir al-Dìn alHanbali argues that at the time of Nūr al-Dīn's reign, there was a renowned scholar namely Majd al-Dīn Tāhir Ibn Nasr Allāh Ibn Jahbal, who was Shaykh alIsläm and expert in Figh (jurisprudence), mathematics and law of inheritance. ${ }^{3}$ He had composed a book about the merit of Jihäd to present it specifically to Nūr al-Dīn (al-Hanbalī, 1999, 2: 102-103). Furthermore, in one of Ibn al-Qaysarānī’ poem which described the victory of Nūr al-Dīn over Josceline, he clearly reiterates the position and merit of Bayt al-Maqdis and al-Aqsā Mosque (Ibn alAthïr, 1963: 103). El-Awaisi (2007: 40-41) argues that 'Since Prophet Muhammad's Night Journey, Bayt al-Maqdis has always been the location and source of Muslim hope. It has been closely linked to the Muslim faith, and has come to represent a living image in Muslim minds and hearts. It has also mobilised the souls, feelings and emotions of Muslims, attaching their hearts to it and making them yearn towards it'. Hillenbrand (1999: 164) argues that it was during the career of Nūr alDin that the idea of liberating Bayt al-Maqdis seems to have been reinforced by official or government-approved propaganda campaign which used the writings on the merit of Bayt al-Maqdis as a weapon.

Some of the religious poetry at that particular era called for Muslim unification and emphasized on Jihäd against the Crusaders and focused on the sanctity of Bayt al-Maqdis especially its centre, al-Aqsā Mosque. For instance, the poet of Ibn Munirr urges Nūr al-Dīn to fight against the Crusaders in which he emphasizes "until you see Jesus fleeing from Jerusalem" (Hillenbrand, 1999:150). Another poet of Ibn al-Qaysarānī reiterates the centrality of Bayt al-Maqdis and its centre, al-Aqsā Mosque, in particular, in the aims of Nūr al-Dīn when he says:

May it, the city of Jerusalem, be purified by the shedding of blood,

The decision of Nūr al-Din is as strong as ever and,

The iron of his lance is directed at al-Aqsā. (Hillenbrand, 1999:151) 
Abū Shāmah narrated an account from Radī al-Dīn Abū Sālim 'Abd alMuncim Ibn al-Mundhir about the story of Nūr al-Dīn and Abū Ghānim Ibn alMundhir whilst they marched towards Shayzar. According to an account from Ibn al-Athïr, the movement of Nūr al-Dīn to conquer Shayzar was in $552 \mathrm{AH} / 1157$ CE (Ibn al-Athīr, 1963: 110; Ibn al-Athīr, 1982, 11: 219). Nūr al-Dīn asked Abū Ghānim to write a letter containing his instruction to eliminate all of the violated policies, which were practiced in Aleppo, Damascus, Hims, Harrān, Sinjār, al-Rahbah, 'Azāz, Tall Bāshir and several other places. In the letter, Nūr al-Dīn clearly referred to 'the conquests of 'Umar Ibn al-Khattāb' (Abū Shāmah, 1956, vol.1: 3839):

May Allah reward them back what has been stolen from their wealth, which Allah already gifted to them during the conquests of cUmar [in historical Syria]...

Thus, it could be argued that the conquests of 'Umar including the first conquest of Bayt al-Maqdis were the practical model adopted by Nūr al-Din in realising his mission. One also can argue that the conquest of Bayt al-Maqdis might well have been his main concern and aim nine years after his succession.

In short, the close-relationship between Nūr al-Dīn and the 'Ulamä' (religious scholars) during his period in which the 'Ulamä' were intimately involved in the military campaigns of Nūr al-Dīn. Some Jihād literature was written as well as the Fadä'il Merits of Bayt al-Maqdis literature was read and extended widely. It could be argued that these measures could have its direct impact on the heart and mind of a Muslim leader like Nūr al-Dīn. Moreover, it could be argued that the vision of liberating Bayt al-Maqdis had rooted a long time among these religious connections before the rise of Nūr al-Dīn. However, the idea had not occupied the agenda of Muslim leaders until the time of Nür alDin. This is due to the fact that he had a strong and special relationship with them.

\section{Preparations: Practical Steps Towards Liberating Bayt al-Maqdis}

The first aim of Nūr al-Dīn was to unite all Muslim territories in Syria under his rule, which had been achieved by the unification of Syria in $549 \mathrm{AH} / 1154 \mathrm{CE}$. For Nūr al-Dīn, the capture of Damascus from Mujīr al-Dīn Abaq was very significant in terms of preparing a strategic base in Syria to fight against the Crusaders systematically. After the death of Imād al-Dīn Zankī, Nūr al-Dīn succeeded his father in Aleppo and his brother, Sayf al-Dīn Ghāzì became the ruler of Mosul. Both of them endeavoured to form a strong alliance and collaboration between Aleppo and Mosul. Ibn al-Athīr and Abū Shāmah assert that a few attempts had been carried out by Nūr al-Dīn and his troops in order to provide supporting force to Mosul and to stay over there. Once, Sayf al-Dīn Ghāzī stated to Nūr alDīn (Ibn al-Athīr, 1963: 88; Abū Shāmah, 1956, 1: 122-123):

It is not my aim that you would stay here [in Mosul] with me, but my aim [from our collaboration] is that for the Kings and the Crusaders, to know our 
agreement [alliance and cooperation]. If there were any attempt [from them] to strike on us, they will not proceed [with their intention].

However, we can argue that their alliance and cooperation were restricted to the areas surrounding Aleppo, Edessa and Mosul while other important territories were still under the control of either several other Muslim kings or the Crusaders. To some degree, the alliance could indicate the authority of the Zanki's family in the north Syria. However, this was not sufficient to launch any massive campaigns towards the Crusaders in the Latin Kingdom of Jerusalem. Instead, Nūr al-Dīn and Sayf al-Dīn had to conquer several other key cities in the north and south of Syria to smooth the progress of their campaigns towards the liberation of Bayt al-Maqdis.

In order to encounter the massive progress of the Second Crusade, Nür alDin realised that Aleppo should be the most powerful Muslim stronghold in the north. Therefore, with the assistance from two experienced lieutenants, Asad alDīn Shirkūh and Majd al-Dīn ibn al-Dāyah, Nūr al-Dīn had successfully established a strong military base in Aleppo in 541 AH/1146 CE. Newby (1983: 68) argues that "Aleppo was the most strategic base for Nür al-Din in which its defences were so strong that it never fell to the Crusaders. In flat and tawny northern Syria, the citadel of Aleppo could be seen three days' march away, which the city itself was protected by great walls". We can argue that the setting up of Nūr al-Dīn's practical steps was well designed with Aleppo as his military base in Syria. The fact that Aleppo has been for a long time under the control of the Muslims may well justify his judgment. Nūr al-Dīn might realise that there was no other appropriate military base but Aleppo in order to launch forthcoming campaigns against the Crusaders.

Moreover, Hillenbrand (2001: 119) argues that the Arab chroniclers enthusiastically record the boost in morale, which the Muslims in Syria experienced with the conquest of Edessa in $539 \mathrm{AH} / 1144 \mathrm{CE}$, under the leadership of 'Imād al-Dīn Zankī, but they are also aware of Edessa's strategic importance. In addition, she argues that Ibn al-Athir pointed out that the Crusaders hold on Edessa had harmed the Muslims and that it was the eye of the Jazirah and the fortress of the Muslim land. Having realised the significance of Edessa to his campaign, Nūr al-Dīn, who was in Aleppo, marched towards the city immediately. This happen after he had heard that Josceline II went to recapture the city with support from the Armenian inhabitants. Indeed, the reconquest of Edessa in $541 \mathrm{AH} / 1146 \mathrm{CE}$ was the first challenge faced by Nūr al-Dìn in order to protect his territories from the Crusaders' attacks. The Crusaders themselves, with this particular attempt, wanted to measure the strength of Nür al-Din, so that they would not underestimate the potency of their enemy. Obviously, Nūr al-Dīn had successfully demonstrated his control in the north with the re-conquest of Edessa in which Ibn al-Athir argues that 'this was the second conquest' (Ibn al-Athir, 1963: 87). Moreover, Stevenson (1907: 153) argues that 
"the gain of Nūr al-Dīn in Aleppo when Edessa was conquered was threefold: its communication with the east was secured, its enemy was now in front and no longer in the rear as well, and it in turn began to encircle what was left of the crusaders territory".

Baldwin argues that the most spectacular of Nūr al-Dīn's victories over the Crusaders was that of Antioch in which Raymond of Antioch and his barons were disastrously defeated and Raymond himself was killed in the battle of Ināb in Safar 544 AH/ June 291149 CE (Setton \& Baldwin, 1955: 515). Runciman (1995, 2: 335) argues that the death of the Prince Raymond of Antioch had left serious dynastic troubles in the ruling Frankish families. Therefore, not only the Principality of Antioch but also other Crusader states were in concern about the current state of affairs in their territories.

According to Abū Shāmah and Ibn al-Athīr, Nūr al-Dīn had successfully conquered Antioch after his second strike in which the successor of Raymond, Reginald of Chatillon was detained (Abū Shāmah, 1953, 1: 156; Ibn al-Athīr, 1982, 11: 144). Stevenson (1907: 167) argues that Nūr al-Dīn's early policy of attack on Antioch had accomplished its immediate purpose and the last of the possessions of Antioch east of the so-called 'backbone of Syria' had been gained by the conquest of the castle of Fāmiyā (Afāmiyah). We may argue that almost three years after the recapture of Edessa in $541 \mathrm{AH} / 1146 \mathrm{CE}$, the conquest of Antioch became the second turning point for Nūr al-Dīn in determining his next practical steps. Having realised that the brawniest stronghold of the Crusaders in the north could be defeated, Nūr al-Dīn might learn a meaningful lesson in the fact that he could possibly gain victory over the remaining Crusaders states.

Finally, Nūr al-Dīn's capture of Damascus in 549 AH/1154 CE marked a significant outcome in the situation of the Muslims in Syria. Prior to the capture, the Muslims were divided into several states and factions. Each entity was administrated by their own ruling family. Stevenson (1907: 173) argues that the acquisition of Damascus by Nūr al-Dīn is a landmark in history, while Baldwin argues that with the unification of all the Muslims in Syria under his rule, Nür alDìn's military power was now consolidated (Setton \& Baldwin, 1955: 519). Brundage (1962: 126) points out that the Second Crusade had done nothing to halt the advance of the Muslims against the Latin states, and in the years immediately following the fiasco of the Crusaders at Damascus, the Muslims advance continued rapidly.

Moreover, Runciman argues that Nūr al-Dìn's capture of Damascus "heavily outbalanced Baldwin's capture of Ascalon. His territory now stretched down the whole eastern frontier of the Crusaders states which are from Edessa to Oultrejourdain. Only a few petty emirates in Syria retained their independence such as Shayzar. Runciman continues to emphasize that though the Crusaders territories were larger in area and richer in resources, Nür al-Din had the advantage of union under one master who was far less trammelled by arrogant vassals than the ruler 
of the Crusaders states was" (Runciman, 1995, vol.2: 341). In the same line of argument, Elisseeff agrees that "the capture of Damascus marked the beginning of a new era for Syria. At the time, Aleppo and Damascus had the same sovereign, but Nūr al-Dīn's state was no more than a mosaic of often mutually hostile emirates" (Elisseeff, 2002: 227).

In short, the capture of Damascus was the peak of Nūr al-Din's practical steps in Syria. This could be considered as the first practical phase towards reconquering the remaining Crusaders states. At the end of the first phase, Nür al-Din had successfully completed two major steps; the Muslim unity in Syria and the strong military foundation for the Muslims in the north. Therefore, according to El-Awaisi's new geopolitical theory, Nūr al-Dīn's subsequent step would be the conquest of Egypt which will lead to the second liberation of Bayt al-Maqdis at the end of the second phase of his movements.

\section{The Conquest of Egypt in $564 \mathrm{AH} / 1169 \mathrm{CE}$}

Based on El-Awaisi's new geopolitical theory, one can argue that Nūr al-Dinn wanted to unite all Muslims under one caliph, the Sunni 'Abbāsid Caliph in Baghdād as a first step to launch massive campaigns against the Crusaders. Nūr al-Din might felt that it is crucial to eliminate and abolish the influences of the Shicites in order to make his path through to Bayt al-Maqdis smooth and without any internal dispute or division. Newby (1983: 23) argues that the political division between Egypt and Bilad al-Sham (Historical Syria) was a source of strength to the Crusaders states. Moreover, he claims that Nūr al-Dīn had no thought of conquering Egypt as a preliminary step to liberate Bayt al-Maqdis for the reason that he could not fight both the Fatimids and the Crusaders at the same time. Therefore, if Nūr al-Dīn were to conquer Egypt, then Bilad al-Sham (Historical Syria) and Egypt will be united and the Muslims themselves will gain massive strength. Ibn al-Athir argues that the Crusaders knew the fact that if Egypt fell under the control of Nür al-Dìn, then they will be in a dangerous situation (Ibn al-Athïr, 1963: 121; Ibn al-Athïr, 1982, 11: 299). We may agree with Newby to the fact that at an earlier stage of conquering Egypt, Nūr al-Din was unenthusiastic but ambitious, and Asad al-Dīn Shirkūh made it possible. In the same line of argument, Stevenson emphasizes that Nūr al-Dīn hesitated to proceed towards Egypt when Shāwar reached Damascus seeking for military support. Instead, he argues that throughout the whole history of the attack on Egypt, Shirkūh was the moving spirit (Stevenson, 1907: 187; Van Der Krogt, 2011).

Indeed, after the Fātimids Shicite of Egypt had fallen, all the territories under the control of Nūr al-Dīn had been restored under the 'Abbāsid Caliph in Baghdād. Lyons and Jackson argue that soon after the elimination of the Fātimids, coins were minted in Egypt with the name of the 'Abbāsid Caliph, alMustadī' on one side and that of Nūr al-Dīn on the other. Nūr al-Dīn himself had sent Sharaf al-Dīn Ibn Abì 'Asrūn to bring the official news of the death of al${ }^{\mathrm{C}} \bar{A} \mathrm{did}$ to Baghdād in which he came back with robes of honour for Nūr al-Dīn and 
Salāh al-Dīn. (Lyons \& Jackson, 1982: 59). From this particular movement, it could be argued that Nūr al-Dīn had successfully united the Muslims in Bilad al-Sham (Historical Syria) and Egypt under one power, the doctrine of Ahl al-Sunnah wa al-Jamä $\bar{a}^{c} a h$ (Sunnī). This could be among the key factors in the process of the unification of the Muslims in the $6^{\text {th }}$ century $\mathrm{AH} / 12^{\text {th }}$ century $\mathrm{CE}$ under the leadership of Nūr al-Dīn.

Evidently, the unification of the Muslims had resulted in immediate positive outcomes in which the Crusaders in the Latin Kingdom of Jerusalem were in the most dangerous situation at the time. Stevenson (1907: 187) argues that "the territories of the Kingdom of Jerusalem intervened between Damascus and Egypt in which the hostility of Amalric had to be reckoned with. With the Muslims in Syria (Bilad al-Sham, Historical Syria) and Egypt under one ruler, the Kingdom of Jerusalem would lie between two fires. From the Delta of Egypt, Nür alDin might employ a fleet against the Syrian coastal areas and interrupt communications with Europe". Indeed, the attack of Salah al-Din on the southwestern territory of Bayt al-Maqdis including districts of 'Asqalan, and outskirts of Gaza in Rabi' al-Thani 566 AH/December 1170 CE and his capture of Aila on the Red Sea has made Amalric alarmed by the situation (Ibn al-Athir, 1982, vol.10:31, Stevenson, 1907:199). The unified forces of Salah al-Din in Egypt (south) and Nur al-Din in Syria (north) could possibly strike the Latin Kingdom of Jerusalem from opposite sides. This critical situation led Amalric to send an embassy to the kings of France and England, but they turned him down. As a result, he asked help from Manuel of Constantinople (Stevenson, 1907:200). In short, the establishment of this encircled area between north and south of Bayt al-Maqdis strengthen the argument that Nur al-Din had done all the required practical steps towards the liberation of Bayt al-Maqdis for the second time in Muslim history.

According to the second circle of El-Awaisi's new geopolitical theory of Barakah Circle Theory of Bayt al-Maqdis, 'Al-Ardh al-Mubarakah is not only Bilad alSham (Historical Syria) or Egypt but both of them together'. El-Awaisi (2007: 30) argues that:

Ignoring this Qur'anic fact has led to the loss of Islamicjerusalem to foreign powers several times in history. However, when the Muslims at the time of (Nur al-Din and) Salah al-Din realised the unity of the two parts of the circle, they liberated Islamicjerusalem from foreign invasion. Indeed, the uniting of Egypt with Syria was an important factor in liberating Islamicjerusalem. Accordingly, the liberation of Islamicjerusalem, one could argue, will not happen until Muslims realise and implement the unity of the two sides in the circle. (Moreover), there is an obvious link between three distinctive places on earth: Islamicjerusalem, Sinai and Makkah. 'By the figs and the olives [in Islamicjerusalem], and Mount Sinai, and this secure land [in Makkah]' (Qur'an, 95:1-3). Indeed, one can argue that there is a unity between al-Sham and 
Egypt, with its centre in Islamicjerusalem, and the Arabian Peninsula, with its centre in Makkah and extending between the Nile and the Euphrates.

Below is the map of the second circle of El-Awaisi's new geopolitical theory of Barakah Circle Theory of Bayt al-Maqdis (El-Awaisi, 2007: 31);

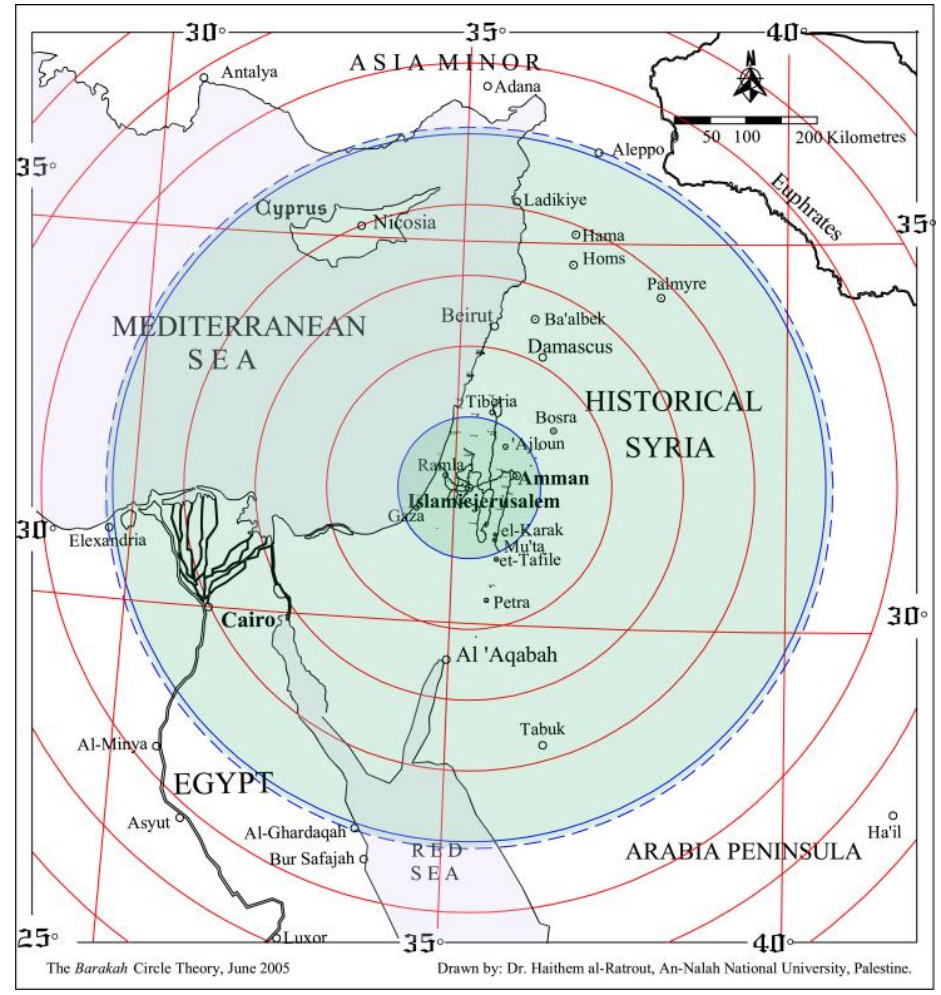

\section{Remaining Evidence: The Construction of the Minbar (Pulpit)}

In the same year (564 AH/1169 CE), Nūr al-Dīn conquest Egypt, he ordered the construction of the minbar. Indeed, this could be seen as a good sign of his preparation to the historical moment of liberating Bayt al-Maqdis. Here, one could trace back the plan of Nūr al-Dīn to liberate Bayt al-Maqdis to his instruction to construct a Minbar for Al-Aqsa Mosque. Tabbaa (2002: 93) argues also that the construction of the Minbar marks the peak of creativity of the Aleppo school of woodcarvers. Tabbaa (2002: 185) also argues that the Minbar which was one of the best-executed and most famous Minbar ever made. Hillenbrand (1999: 152) argues that according to Tabbaa, the Minbar is an eloquent statement of Jihād in which it was the richest of all Nūr al-Dīn's inscriptions in proclamation of the victory of Islam against the infidels. Indeed, the inscription on the Minbar is very unusual, both in length and in its emotional invocations to Allah. Indeed. Ibn Jubayr (1980: 227), who visited Aleppo in 580 
$\mathrm{AH} / 1185 \mathrm{CE}$, illustrate the uniqueness of the Minbar in which he writes in his 'Rihlah Ibn Jubayr':

I have not seen in any other country a Minbar which resembles its shape and the uniqueness of its manufacture... It raises like an enormous crown above the Mihräb until it reaches the ceiling. (Hillenbrand 1999: 160).

Tabbaa (2002: 63) argues that the calligraphic transformation in the monuments was one of the most visible signs of Nür al-Dīn's broad movement, which had lain dormant in Syria during the turbulent decades of the first half of the twelfth century. Tabbaa (2002: 94) also argues that perhaps not coincidentally, some of the finest works in Syria in the mid- $6^{\text {th }}$ century $\mathrm{AH} / 12^{\text {th }}$ century CE were commissioned by Nūr al-Dīn for his various institutions in Aleppo, Hamāh, Damascus and even in Bayt al-Maqdis. Indeed, these monuments had conveyed the character of Nūr al-Dìn as the Jihäd fighter against the Crusaders in Bilad al-Sham (Historical Syria).

Nūr al-Dīn himself had ordered a Minbar to be built, some five years before his death, with the intention to place it in al-Aqsā Mosque after liberating Bayt al-Maqdis. Evidently, some inscriptions that have been found revealed the strong vision and eagerness of Nür al-Dīn to liberating Bayt al-Maqdis and return it back under the Muslim rule (Hillenbrand, 1999: 151 \& 161). The two dates engraved in the Minbar $564 \mathrm{AH} / 1168-9 \mathrm{CE}$ and $572 \mathrm{AH} / 1176 \mathrm{CE}$ suggests that its construction begun at the time of Nūr al-Dìn but perhaps not completed until the reign of his son al-Sălih Ismāīil. One of the inscriptions on the Minbar stated that it had been commissioned by Nūr al-Din in 564 AH/1168-9 CE. The beginning of the inscription reads:

Its construction has been ordered by the servant, the one needful of His mercy, the one thankful for His grace, the fighter of Jihäd in His path, the one who defends against the enemies of His religion, the just king, Nūr al-Din, the pillar of Islam and the Muslims, the dispenser of justice to those who are oppressed in the face of the oppressors, Abū al-Qāsim Mahmūd b. Zankī b. Aq Sunqūr, the helper of the Commander of the Faithful. (Hillenbrand, 1999:152).

Nūr al-Din had appointed four outstanding carpenters whose signatures appeared on the inscriptions of the Minbar. Tabbaa (2002: 94) mentions that the Minbar was signed by four different artisans: Humayd Ibn Zāfir, Abū al-Hasan Ibn Yahyā, Abū al-Fadā'il Ibn Yahyā and Salmān Ibn Macālī all from the village of Akhtarin in the vicinity of Aleppo. The recent analysis of its geometric patterns, preliminary studies for building a replica, shows that it contained twenty-five different geometric patterns in its various panels in addition to vegetal arabesque, openwork, muqarnas and inscriptions.

It is significant to indicate here that the text of the inscription seems even to be asked Allah to grant him a personal favour in liberating Bayt al-Maqdis himself; 'May He grant liberation to him (Nūr al-Dīn) and at his own hand.' AlBundārī (1989: 314-315) in his summary of 'al-Barq al-Shāmì' by 'Imād al-Dìn al- 
Kātīb recorded the story of the Minbar before it was brought to Bayt al-Maqdis in which he says:

By the light of his discernment the just prince Nūr al-Dīn Mahmūd b. Zankī had known in his time about the conquest of Bayt al-Maqdis after him. So, he commissioned in Aleppo the making of a Minbar for Bayt al-Maqdis; carpenters, craftsmen and architects laboured on it for years and they made it outstand in its solidness and decoration. That Minbar remained installed in the mosque of Aleppo, sheathed like a sword in the scabbard of protection until the sultan (Salāh al-Dīn) in this age ordered the fulfilment of the Nür al-Din's vow and the minbar was brought to its place in Bayt al-Maqdis. (Hillenbrand 1999: 156).

However, Ibn al-Athīr's account regarding the Minbar of Nūr al-Dīn seems more provoking and admiring. Ibn al-Athir (1982, 11: 551-552) states that:

He (Salāh al-Dinn) ordered that a Minbar should be made for him. He was told that Nūr al-Dīn Mahmūd had made a Minbar in Aleppo. He ordered craftsmen to go to great lengths to decorate it beautifully and to perfect it and he said: "we have made it to be erected in Bayt al-Maqdis." So, carpenters made it in a number of years in which nothing like it was made in Islam. So, he (Salāh al-Dīn) ordered that it should be brought, and it was carried from Aleppo and erected in Bayt al-Maqdis. Between the making of the Minbar and its being carried (to Bayt al-Maqdis) was more than twenty years. This was one of the blessings and good intentions of Nür al-Dīn, may Allah have mercy on him. (Hillenbrand 1999: 156).

It could also be argued that Nūr al-Dīn's had intentionally decided to constructer a Minbar and not ant other Muslim monuments. This is due to the fact that the Minbar signifies the most important part of a mosque in Islamic tradition. Therefore, creating a Minbar to be installed in al-Aqsā Mosque in Bayt al-Maqdis indicate the fact that Nūr al-Dīn optimistically knew that the liberation of Bayt al-Maqdis would be accomplished in the near future. Additionally, Nūr alDin had understood, definitely, that the Minbar would last for centuries and this could be the most significant monument in Bayt al-Maqdis in the context of Jihäd and counter-Crusades. The Minbar was first used in the Great Mosque of Aleppo and was eventually brought to Bayt al-Maqdis after the death of Nūr al-Dīn at Salāh al-Dīn's request. The Minbar remained in al-Aqsā Mosque for about eight centuries from $564 \mathrm{AH} / 1168 \mathrm{CE}$ until it was destroyed by an Australian fanatic in 1969 CE. as part of a systematic planned attempt to destroy Al-Aqsa Mosque.

On the other hand, Hillenbrand (1999: 160) claims that the inscription in alJāmic al-Nūrī in Mosul, in particular verse 149 from Sūrah al-Baqarah; "From wherever you start forth, turn your face in the direction of the Sacred Mosque (in Makkah); that is indeed the truth from your Lord. And Allah is not unmindful of what you do.", is another evidence to support the argument that Nür al-Dīn was preoccupied with Bayt al-Maqdis. We disagree with what Hillenbrand presented as evidence. This verse is only asking Muslims to turn their face towards the 
Ka'bah in Makkah when they are praying. Most if not all the mosques in the Muslim countries have engraved such a verse.

In short, the construction of the Minbar and its uniqueness proved the seriousness of Nūr al-Dīn in his plan towards the liberation of Bayt al-Maqdis. Moreover, the construction of the Minbar seems to be the most noticeable remaining evidence representing the strong vision of Nūr al-Dīn towards Bayt alMaqdis and part of his preparations plan.

\section{CONCLUSION}

It seems obvious that all these practical steps are apparent indications of the plan of Nūr al-Dīn towards the liberation of Bayt al-Maqdis. His campaigns from Aleppo in the north towards Damascus and Cairo in the south appeared to be part of strategic military steps in order to move at a later stage to liberate Bayt al-Maqdis. Using the same argument of El-Awaisi (2007: 49) regarding the first Muslim conquest, we argue that the second Muslim conquest of Bayt al-Maqdis, 13 years after the death of Nūr al-Din (569 AH/ $1174 \mathrm{CE}$ ), "was a natural progression. These events helped to create a supportive environment which would help to establish and direct future events. Indeed, they were preliminary steps on the way to the great campaign which was launched and directed' by Nūr al-Din and crowned by the conquering of Bayt al-Maqdis by Salah al-Din in $569 \mathrm{AH} / 1174 \mathrm{CE}$.

In comparison with 'the first Fatih of Bayt al-Maqdis (El-Awaisi, 2007: 3749), the practical steps of Nūr al-Dìn were following the same pattern of the Prophet Muhammad's steps of preparations. Although these preparations for the first conquest started at the time of the Prophet Muhammad, it was only concluded by the first and second Muslim Caliphs, Abu Baker and Umar Ibn alKhattab. Nūr al-Dīn, like Prophet Muhammad, died before fulfilling his mission to liberate Bayt al-Maqdis. Salah al-Din, like Abu Bakr and Umar Ibn al-Khattab, took the leadership and accomplished his mission. From these two turning points in the history of liberating Bayt al-Maqdis, we learn that well preparations at all fronts are essential steps for concluding the liberation successfully. This might take generations of preparations and it will not happen suddenly. Indeed, one verse of the Qur'an instruct Muslims to 'prepare against them (make ready) whatever you are able of power and of steeds of war by which you may frighten the enemy of Allah and your enemy and others besides them whom you do not know [but] whom Allah knows' (Qur'an: 8: 60).

Finally, the plan of Nūr al-Dīn for liberating Bayt al-Maqdis went through two main stages. First: Nūr al-Dīn's concern has been developed as early as he succeeded his father, 'Imād al-Dīn Zankī in Aleppo. Putting the ideas of Muslim scholars, in particular, al-Sulamì into action, Nūr al-Dīn started to conquer several states which were under the Crusaders occupation one by one. This began with the re-conquest of Edessa and concluded with the conquest of Egypt. This 
argument would be supported with the appearance of internal disagreement in $567 \mathrm{AH} / 1172 \mathrm{CE}$ between Nūr al-Dīn and Salāh al-Dīn in which Ibn al-Athīr had recorded in detail (Ibn al-Athïr, 1963: 158-159; Ibn al-Athïr, 1982, 11: 371-372). This disagreement emerged as a result of the negligence and lack of enthusiasm from Salāh al-Dīn's side to carry out Nūr al-Dīn's plan to march towards Karak and Shawbak and later on headed for the liberation of Bayt al-Maqdis. Moreover, Elisseeff (2002: 230) argues that reconquest and unity were two new slogans in the written propaganda, essentially in the re-conquest of al-Sāhil (the Mediterranean coast) and of Bayt al-Maqdis.

Second: Nūr al-Din's plan for Bayt al-Maqdis reached its peak towards the end of his life. It could be claimed that after his defeat to the Crusaders at the battle of al-Buqaycah in $558 \mathrm{AH} / 1163 \mathrm{CE}$, Nūr al-Dīn suffered a lot. Hillenbrand argues that this could be the most important turning point in the religious development of Nūr al-Dīn. This defeat had a yawning consequence on the personal life and policies of Nür al-Dīn during the rest ten years of his reign. From this time forth, he adopted a life of piety and asceticism (Hillenbrand, 1999: 134). However, according to Ibn al-cAdim, there was an early incident before the battle of al-Buqay'ah, which seems to have re-sharpened Nūr al-Dīn's religious determination. Burhān al-Dīn al-Balkhī, who died in 1153, before capturing Damascues, said to Nūr al-Dīn: "Do you want to celebrate victory whilst in your camp there are intoxicating drinks and drums and wind instruments?". According to this narration, Nūr al-Din was deeply affected by these reprimands and he vowed regret and repentance (Ibn al-Adim, 1996: 306). This argument could be strengthened by the fact that Nūr al-Dīn's campaigns towards the conquest of Egypt only achieved after the third mission sent under Asad al-Din Shīrkūh which was in $564 \mathrm{AH} / 1169$ CE. Therefore, Nūr al-Dīn realised that he had acquired strong power in which the Muslims had established an encircled area around the Latin Kingdom of Jerusalem from Aleppo and Antioch in the north to Cairo in Egypt in the south. Perhaps he thought that he could further move towards the Latin Kingdom of Jerusalem and it is the right time to liberate Bayt al-Maqdis from the Crusaders. His order to construct the Minbar in the same year of the conquest of Egypt in 564, could be argued as a good sign of Nūr al-Dīn's preparation to the historical moment to liberate Bayt al-Maqdis.

What is more convincing, regarding the central argument of this article, was the fact that he did mention clearly his plan in a letter sent to the 'Abbāsid caliph in Baghdād. Abū Shāmah recorded the text of the letter of Nūr al-Din to al-Mustadī' Ibn Amr Allāh in 568 AH/1173 CE, a year before his death, in which Nūr al-Din stresses the urgent need to liberate Bayt al-Maqdis from the Crusaders. He emphasizes that his main aim is to banish the worshippers of the cross from alAqsā Mosque. The content of the letter revels the intention of Nūr al-Dīn to liberate Bayt al-Maqdis. It reads: 
And Constantinople and Bayt al-Maqdis are running to the conquests time in the field of competition. Both of them are in the desolation of the night of the black darkness waiting in the morning of the intimacy. May Allah with His generosity brings near the harvest of the both conquests to the Muslim and guides the servant to the possession of satisfaction of the Creatures. (Abū Shāmah, 1956, 1: 547-548).

At the end of the letter, Nūr al-Dīn revels precisely his strong consciousness and plan in liberating Bayt al-Maqdis. Its read:

And we ask Allah for His guidance to lead to the accomplishment of the aim, and the exclusion of the dirty worshippers of the cross from Al-Aqsā Mosque. May Allah the Almighty make the liberation of Bayt al-Maqdis His starting point of His will, and the goal of His trigger and His suggestion in its fight; and help him (Nūr al-Dīn) to reinstate his authority in al-Sāhil (coastal area) including all of its countries (Bilad al-Shām). (Abū Shāmah, 1956, 1: 548).

An additional supporting evidence comes from Ibn al-Jawzī who had mentioned clearly that the ultimate goal of Nūr al-Dīn was to liberate Bayt alMaqdis from the Crusaders.

He (Nūr al-Dīn) regularly wrote to me (seeking my advice) ... and he set his goal for the liberation of Bayt al-Maqdis but his death on Syawal this year (569 AH/1174 CE) made it impossible... (Ibn al-Jawzī, 1995, 18: 209-210).

In short, the knowledge foundation and preparation through the call for Jihād of al-Sulamī, the writing on Jihād by Muslim scholars, in particular Ibn Jahbal, and Nūr al-Dīn intimate relationship with the Muslim scholars in Syria were the main factors behind developing his plan towards the second liberation of Bayt al-Maqdis; which was well developed during his first phase of his reign in Syria. Indeed, this article shows that the liberation of Bayt al-Maqdis for Nür alDin was in his heart and mind; and it was his ultimate aim behind several practical steps throughout twenty-eight years of his reign. According to ElAwaisi's new geopolitical theory, Nūr al-Dīn's practical steps which can be divided into two major series of campaigns; the unification of Bilad al-Sham (Historical Syria) at the local level, and he conquest of Egypt at the regional level, could be considered as Nūr al-Dīn most excellent achievement throughout the Muslim history. Indeed, Nūr al-Din has paved the way to the second Muslim liberation of Bayt al-Maqdis in 583 AH/ 1187 CE by Salāh al-Dīn, 13 years after the death Nūr al-Dīn. In other words, Nūr al-Dīn's preparation plan was his outstanding contributions towards the liberation of Bayt al-Maqdis for the second time in Muslim history. 


\section{REFERENCES}

Abū Shāmah, Shihāb al-Dīn 'Abd al-Rahmān Ibn Ismācīl (1956) Kitāb al-Rawdatayn fĩ Akhbār al-Dawlatayn: al-Nüriyyah wa al-Salāhiyyah. Beirut: Mu'assasah al-Risālah.

Al-cAsalī, Kāmil (1981) Ajdādunā fĩ Tharā Islamicjerusalem, cAmmān: Mu'assasah Āli al-Bayt.

El-Awaisi, Abd al-Fattah (2007) Introducing Islamicjerusalem (Scotland: Al-Maktoum Institute Academic Press), $3^{\text {rd }}$ edition.

El-Awaisi, Khalid (2007a) Mapping Islamicjerusalem: A rediscovery of geographical boundaries. (Scotland: Al-Maktoum Institute Academic Press).

Brundage, James A (1962) Crusades: A Documentary Survey. Milwaukee: The Marquette University Press.

Al-Bundārī, al-Fath Ibn 'Alī (1989) Sanā al-Barq al-Shāmī: Ikhtisār al-Fath ibn cAlī al-Bundārī min Kitāb al-Barq al-Shāmī. Riyād: Dār al-Liwā'.

Elisseeff, Nikita (1967) Nur ad Din: un grand prince musulman à l'époque des croisade's, Damascus: Institut Francais de Damas.

Elisseeff, Nikita (2002) 'The Reaction of the Syrian Muslims after the Foundation of the First Latin Kingdom of Jerusalem' in The Crusades: The Essential Readings, edited by Thomas F. Madden. Oxford: Blackwell Publishers.

Al-Hanbalī, Mujīr al-Dīn (1999) Al-Uns al-Jalīl bi Tārīkh al-Quds wa al-Khalīl. Hebron: Maktabat Dandis.

Hillenbrand, Carole (1999) The Crusades: Islamic Perspectives, Edinburgh: Edinburgh University Press.

Hillenbrand, Carole (2001) 'Abominable Acts: The Career of Zengi' in The Second Crusade: Scope and Consequences, ed. Jonathan Phillips and Martin Hoch. Manchester: Manchester University Press.

Ibn al-Adim (1996) 'Umar Ibn Ahmad. Zubdah al-Halab min Tārīkh Halab. Beirut: Dār alKutub al-cllmiyyah.

Ibn al-Athīr, Abū al-Hasan cAlī al-Shaybānī (1963) al-Tārīkh al-Bāhir fĩ al-Dawlah alAtābikiyyah bi al-Mawsil. Cairo: Dār al-Kutub al-Hadīthah.

Ibn al-Athīr, Abū al-Hasan 'Alī al-Shaybānī (1982) al-Kāmil fĩ al-Tārīkh, Beirut: Dār Beirut.

Ibn al-Jawzī, Abū al-Faraj cAbd al-Rahmān ibn cAlī (1995) al-Muntazạm fĩ Tārīkh al-Mulūk wa al-Umam, Beirut: Dār al-Kutub al-cllmiyyah.

Ibn Jubayr, Abū al-Husayn Muhammad ibn Ahmad (1980) Rihlah Ibn Jubayr, Beirut: Dār Sādir.

Lyons, Malcolm C. and Jackson, David E.P (1982) Saladin: The Politics of the Holy War. Cambridge: Cambridge University Press.

Newby, Percy H (1983) Saladin in His Time. London: Faber and Faber.

Runciman, Steven (1995) A History of The Crusades. London: Penguin Books.

Setton, Kenneth M. \& Baldwin, Marshall W (1955) A History of the Crusades. Philadelphia: University of Pennsylvania Press.

Stevenson, William B (1907) The Crusaders in the East: A Brief History of the Wars of Islam with the Latins in Syria During the Twelfth and Thirteenth Centuries. Cambridge: Cambridge University Press.

Tabbaa, Yasser (2002) The Transformation of Islamic Art during the Sunnī Revival. London: I.B.Tauris.

Van Der Krogt, C (2011) Saladin: The Sultan and his times 1138-93. Islam and Christian Muslim Relation, 22(2), 2011: 227-229.

Al-Ziriklī, Khayr al-Dīn (1999) Al-Aclām: Qāmūs Tarājim li Ashhar al-Rijāl wa al-Nisā' min al'Arab wa al-Mustacribīn wa al-Mustashriqin, Beirut: Dār al-c Illm li al-Malāyīn. 


\section{ENDNOTES}

1 "Islamicjerusalem (one word) is a new terminology for a new concept, which may be translated into the Arabic language as Bayt al-Maqdis or Bayt al-Maqdis. It can be fairly and eventually characterised and defined as a unique region laden with a rich historical background, religious significances, cultural attachments, competing political and religious claims, international interests and various aspects that affect the rest of the world in both historical and contemporary contexts. It has a central frame of reference and a vital nature with three principal intertwined elements: its geographical location (land and boundaries), its people (population), and its unique and creative inclusive vision, to administer that land and its people, as a model for multiculturalism, cultural engagement and Aman (peaceful co-existence and mutual respect)". See the original definition in Abd al-Fattah El-Awaisi (2007: 11). For the boundaries of Islamicjerusalem see El-Awaisi (2007a).

2 Al-Sulamī is 'Alī ibn Tāhir ibn Jacfar ibn 'Abdullah Abū al-Hasan al-Qaysī al-Sulamī al-Nahwī, born in $431 \mathrm{AH} / 1039 \mathrm{CE}$ and died on 21st of Rabī al-Awwal $500 \mathrm{AH} / 1106 \mathrm{CE}$. A well-known Damascene jurist and philologist, he is considered a trustworthy scholar and a religious man (Yãqūt al-Hamawī, 1999, 5: 151-152; Ibn 'Asākir, 1996, 43: 4; al-Suyūtī, n.d., 2: 170).

3 Majd al-Dīn Tāhir ibn Nasr Allāh ibn Jahbal taught at al-Madrasah al-Nūriyyah in Damascus and is believed to be the first scholar who taught at al-Madrasah al-Salähiyyah in Islamicjerusalem. He was born in Aleppo and died in Islamicjerusalem in 596AH at the age of 64. (al-Hanbalī, 1999, 2: 102-103; al-Ziriklī, 1999, 3: 223; al-'Asalī, 1981: 226). 